INDEPENDENT JOURNAL OF MANAGEMENT \& PRODUCTION (IJM\&P) http://www.ijmp.jor.br

v. 12, n. 4, May-June 2021

ISSN: 2236-269X

DOI: 10.14807/ijmp.v12i4.1363

\title{
MANAGERIAL STYLES AND THEIR RELATIONSHIP WITH JOB SATISFACTION IN INFORMATION TECHNOLOGY COMPANIES
}

\author{
Anna Beatriz Bezerra Grecco \\ DXC Technology, Brazil \\ E-mail:anna.grecco@outlook.com \\ Daniel René Tasé Velázquez \\ Methodist University of Piracicaba (UNIMEP), Brazil \\ E-mail:dtasev88@gmail.com \\ Lorena Hernández Mastrapa \\ Methodist University of Piracicaba (UNIMEP), Brazil \\ E-mail: lorenahmastrapa@gmail.com
}

Submission: 6/12/2020

Accept: 7/30/2020

\section{ABSTRACT}

The purpose of this paper is to identify and evaluate which managerial style prevails in the operational area of five IT companies and their relationship with the job satisfaction of their employees. For data collection, a questionnaire was applied to 120 participants, validating 110 responses. Questions regarding the three factors of $E A E G$ were integrated in order to identify the focus in which the leadership predominantly operates in these companies, and the five dimensions of $E S T$ were used to measure the level of employees satisfaction regarding each dimension evaluated. Descriptive statistical processing allowed to observe that the managerial style focused on the Task prevails, with an overall average score of $\bar{v} t=4.11$. As dispersion measures, the sample standard deviation $(S t=0.39)$ and sample amplitude $(A t=0.91)$ corresponding to this factor (Task) were calculated, respectively, showing that the values are very close to the average score. It indicates that there is uniformity between the scores for each item of the factor Task. It was found that $65 \%$ of participants confirm the role of the leadership focused on the Task. The Satisfaction with the nature of work dimension reached an average score of $\bar{v} d=5.09$, showing employee satisfaction. The dimension Satisfaction with colleagues reached an average score of $\bar{v} d=4.34$ indicating indifference on the level of satisfaction, whereas the dimensions Satisfaction with salary, promotions and leadership, reached averages of $\bar{v} d=3.87, \bar{v} d=3.70$ and $\bar{v} d=3.46$, respectively, indicating levels 
DOI: 10.14807/ijmp.v12i4.1363

of dissatisfaction. Finally, were highlighted some criteria as motivators for avoid turnover in organizations that contribute to the job satisfaction of these employees.

Keywords: managerial styles assessment; job satisfaction; information technology (IT)

\section{INTRODUCTION}

Employee satisfaction within organizations is a relevant topic that is constantly being studied since good professional performance contributes to an organizational success in a competitive market, mainly due to the fact that job satisfaction is related to several other constructs and behaviors, such as, commitment and productivity; in contrast and negatively, to work stress and absenteeism (Rueda et. al., 2012).

Vroom (1994), believed that satisfaction was the cause of relevant behaviors for good progress of the work, thus, reflecting on indicators of good performance, high productivity, few failures, among others. Organizations with satisfied employees make satisfied customers, so the more quality and favorable conditions there are in the work environment, the better the results presented.

Studies address and evaluate the negative experiences and consequences that employees may have, as a result of their experience in work activities (Warr, 2007). Hence, it was identified: devaluation of human capital, absence of adequate working conditions, even of remuneration and benefits, organizations where the value system is unacceptable or incompatible with the individual, monotonous tasks and a leadership style that retains participation and development of employees, condemning them to feelings of frustration, pessimism and poor performance (Maio, 2016).

Thus, it becomes relevant to know which practices, actions or characteristics of leadership can positively influence the satisfaction and interpersonal relationship of the team, enabling a positive experience in the organization (Sant'anna et al., 2012). Teams are selfdirected and self-motivated, when their leaders understand that their roles are fundamental in the satisfaction of the teams, being able to comprehend and manage them (Batista et al., 2016). If leaders are not attentive, willing to change, mature and update themselves with the changes taking place in the business environment, they will put their organizations at risk (Hunter, 2004).

Currently, with the increasing demand for products and services in the Information Technology (IT) market, active organizations in this field seek to remain competitive, 
INDEPENDENT JOURNAL OF MANAGEMENT \& PRODUCTION (IJM\&P)

http://www.ijmp.jor.br

v. 12, n. 4, May-June 2021

ISSN: 2236-269X

DOI: 10.14807/ijmp.v12i4.1363

profitable, with high approval rate in the face of volatile competition, dedicating themselves to serving their investors. and customers (Rossetti \& Morales, 2007). Leading organizations are looking for professionals who are able to play a leading role with excellence, motivating their teams and collaborating with the organization's success, to ensure the superiority of their products and services (Leucotron, 2019).

In the existing socioeconomic scenario it is expected that every individual has skills of behavioral and technical nature, so they know how to deal with the subjectivity of human nature in their areas of expertise, as the success and survival of organizations are increasingly dependent on the people skills, since, using their knowledge and proficiencies, they meet the demands of their customers (Lopes et al., 2017).

A study carried out by LoveMondays identified that the IT sector is one of the most dissatisfied in terms of salary and benefits within organizations (Exame, 2014). According to the article published (online) in the Careers section of the digital edition of EXAME magazine (2015), the good climate in the work environment is the element that most impacts the satisfaction of Brazilian professionals, being ahead of the possibility of earning a high salary.

Appearing ahead of the remuneration value construct, other aspects such as benefits, professional competence of colleagues and the relationship between them are also shown to be a very important requirement. In this same edition (Exame, 2015), on the 24 areas studied, IT and telecommunications stood out that the most valued aspects that directly impact on job satisfaction are: the work environment, corporate benefits and flexibility.

In IT organizations, control needs to be replaced by cooperation, dialogue and collaboration. These companies are characterized by being knowledge-intensive and having a strong dependence on work in project teams, which are primary production units. Being the leadership and the managerial styles critical components, because it is through the style adopted by the leader, that one can contribute with the transformation of diverse individuals and of different origins, levels of proficiency and experience, in a cohesive team, that can collaborate with the increase in productivity and the commitment on all together achieve the strategic and operational objectives of the organization (Lopes et al., 2017). Once employees are engaged and, with a sense of responsibility and cooperation, the organization becomes different from its competitors.

However, situations are experienced where the relationships between managers and employees collide, reproducing dissatisfaction in the professional sphere, negatively 
DOI: 10.14807/ijmp.v12i4.1363

influencing the results and performance of these organizations. This is due to the managerial style adopted, which does not match the needs of the organization or the team, preventing it from building a high performance group with autonomy and focus on results (Braga et al., 2014; Lopes et al. , 2017; Maamari \& Majdalani, 2017).

Thus, it is necessary to understand how managerial styles are related to the job satisfaction of employees in IT companies. This will help to adopt the necessary measures to transform and aggregate these relationships in a positive way. Hence, with the development of this work, it is intended to identify and assess which managerial styles prevail in the operational area of five small IT companies and their relationship with the job satisfaction of these employees. With this, one can cooperate to enhance the quality of interpersonal relationships, equally, with the aspects that foster satisfaction within the team.

\section{METHODOLOGY}

Initially, a bibliographic research was carried out in order to identify the main theoretical foundations on the subject under study and to understand the concepts related to job satisfaction, leadership, leadership styles, like them and satisfaction at work are related, as well as, the organizational climate and culture. Table 1 presents the main revised documents that served as a basis for understanding the concepts covered in this work.

Table 1: Main studies consulted

\begin{tabular}{l|l}
\hline Approach & Author \\
\hline Job satisfaction & Locke (1969; 1976); Siqueira (2008) \\
\hline $\begin{array}{l}\text { Leadership } \\
\text { Melo (2004); Turano e Cavazotte (2016); Barbosa et al. (2017); Maamari e Majdalani } \\
\text { (2017) }\end{array}$ \\
$\begin{array}{l}\text { Climate, culture and } \\
\text { behavionion }\end{array}$ & $\begin{array}{l}\text { Deal and Kennedy (1982); Schein (1992); Neves (2001); Hellriegel et al. (2001); Santos } \\
\text { and Gonçalves (2010); Maamari and Majdalani (2017); Nunes and Zanetti (2017) }\end{array}$ \\
\hline $\begin{array}{l}\text { Leadership, } \\
\text { Management and IT }\end{array}$ & Souza (2004); Carvalho (2010); Foina (2012); Foina and Eiras (2016); Lopes (2017) \\
\hline
\end{tabular}

As a primary source of data collection, a qualitative and exploratory approach based on semi-structured interviews and a questionnaire made available online and semi-face-to-face was used to identify the judgment that employees have regarding the managerial style perceived in their work environment, for example. Through the application of the Managerial Styles Assessment Scale (EAEG - Escala de Avaliação dos Estilos Gerenciais), from Melo (2004); and, the indicative degree of job satisfaction of employees, referring to the five dimensions assessed in the Job Satisfaction Scale (EST - Escala de Satisfação no Trabalho), from Siqueira (2008). 
DOI: $10.14807 /$ ijmp.v12i4.1363

The questionnaires were available and shared via social media and e-mail containing sociodemographic questions (age, sex and working time (years) in the company); also the questionnaires alluded the dimensions of the EST grouping the items corresponding to each one, and; containing those related to the three focus areas for which managers act according to EAEG. Each interviewee was properly instructed on the concepts evaluated with the support of the studied approaches as a result of the initial bibliographic search (Table 1). A quantitative approach was used on the statistical processing of the questionnaire responses to assess the EAEG and EST results.

\subsection{Managerial Styles Assessment Scale (EAEG)}

Management refers to the activities performed by mangers, but a manager who is able to influence and guide a group to achieve a goal, becomes a leader, in addition of being manager (Melo, 2004; Judge et al., 2004). According to Melo (2004), the performance of leaders turns to one of the following three aims: the task, the relationship and the situation. Figure 1 presents the definitions of each factor in these two authors point of view.

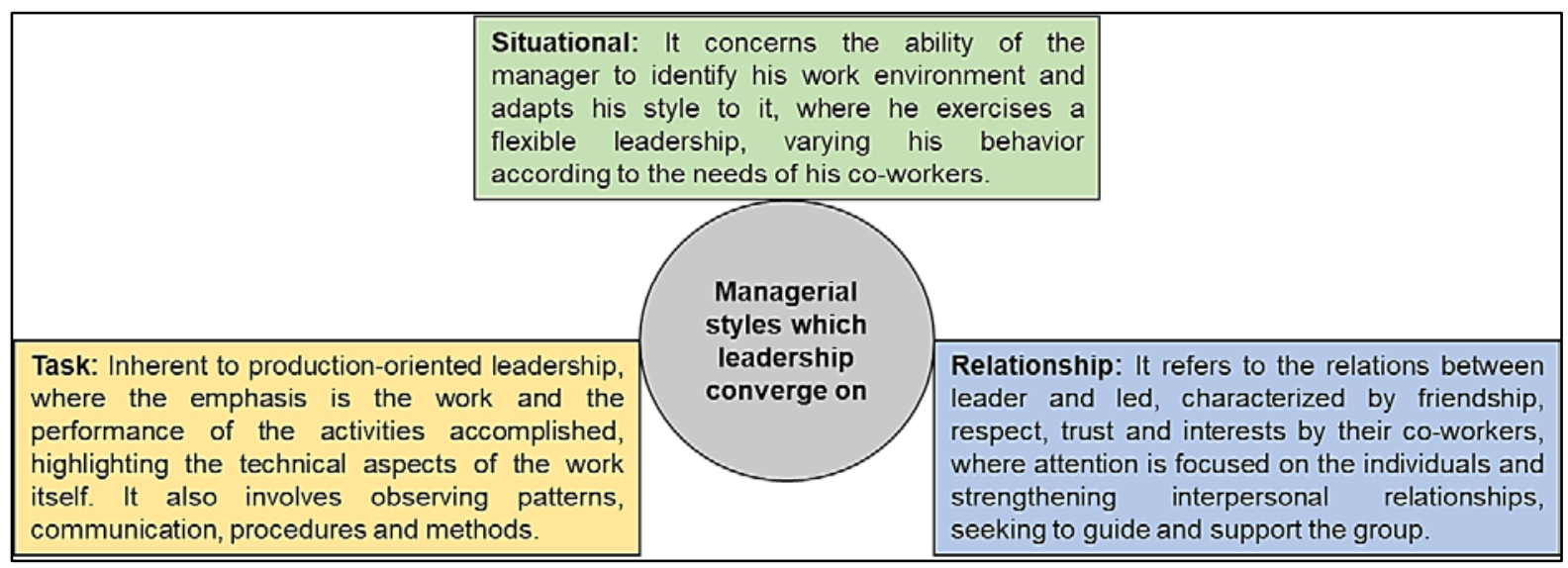

Figure 1: Leadership convergence on managerial styles

EAEG aims to expose the behavior of the leader on a daily basis regarding to the employees he leads. This tool is the result of a study developed in Melo (2004), in universities abroad in order to map the behavior and managerial style of leaders and members of management teams in several corporations. Based on the three factors presented in Figure 1, after validation (semantic and factorial), EAEG was made up of 19 constructs, 9 referring to Relationship factor, 6 to Task, and 4 to Situational (Melo, 2004). A 5-point scale, where, $1=$ never acts like this; 2 = rarely does so; 3 = occasionally does so; $4=$ often does so and $5=$ always does so, allows to calculate an average score and realize what leadership style is adopted in a given work environment (Melo, 2004; Judge et. al., 2004). 
DOI: 10.14807/ijmp.v12i4.1363

The questionnaires used to assess the leadership convergence were processed statistically in a Microsoft Excel ${ }^{\circledR}$ spreadsheet, analyzing each factor and its items (constructs) independently, in order to measure, by grouping the individual results of each questionnaire, the general trend, regarding the respondents perception, of the managerial style that governs the work environment.

The statistical analysis (descriptive) of each key factor ( $k f$ ), namely, Relationship $(r)$, Situational (s), and Task $(t)$, allowed to calculate the average score value $(\bar{v} f)$ as a measure of central tendency, which indicates that the greatest value, leadership and managers turn onto that factor ( $f$ ), which can be Relationship ( $r$ ), Situational (s), and/or Task ( $t$ ). As dispersion measures, the sample standard deviation $(S)$ and the sample amplitude $(A)$ were also determined.

A low value of $S$ indicates that there is uniformity in the values obtained in the scoring of each item $(i=1, \ldots, 5)$ of the evaluated factors $(r, s, t)$ and that these values are closer to the sample mean indicating a minor error. Lower values of $A$ indicate that there is little difference between the maximum and minimum score corresponding to the item (i) of a given factor ( $r$, $s, t$ ), thus, proving by the result of the two variables that there is uniformity in the point scale generated for that factor that is assessed.

Equations 1 to 3 were used to calculate $\bar{v} f, s f$ and $A f$, respectively.

$$
\begin{aligned}
& \bar{v} f=\left[\frac{\left(\sum \text { vif }\right)}{k f}\right] ; f=r, s, t ; k f=9,4,6 ; \\
& S f=\sqrt{S f^{2}}=\sqrt{\sum_{i=1}^{n} \frac{(v i-\bar{v} f)^{2}}{n-1}} ; n=9,4,6 ; \\
& A f=v i f(\max )-v i f(\min ) ; f=r, s, t ;
\end{aligned}
$$

Table 2 shows the items related to each factor, Relationship, Situational and Task. As an indication of the verified accuracy of the scale, Cronbach's alpha reliability coefficient $(\alpha)$

\begin{tabular}{|c|c|c|}
\hline No. & Factors & $\begin{array}{r}\text { Description } \\
\end{array}$ \\
\hline 1 & & Allows time to debate with group members (24) \\
\hline 2 & & Has a caring attitude in the relationship with collaborators (1) \\
\hline 3 & $\Xi$ & Interested in the feelings of the employees under his leadership (12) \\
\hline 4 & 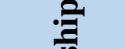 & It is accessible to the led (25) \\
\hline 5 & 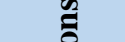 & Demonstrates respect for the ideas of the led (13) \\
\hline 6 & 象 & Encourages the presentation of new ideas in the workplace (19) \\
\hline 7 & $\frac{\pi}{2}$ & Demonstrates confidence (21) \\
\hline 8 & & Leader is understanding with the failures and errors of his led (6) \\
\hline 9 & & Encourages its followers to express their opinions about work (17) \\
\hline
\end{tabular}
for each factor is $\alpha=0.94, \alpha=0.82$ and $\alpha=0.72$, respectively.

Table 2: Factors and description of each item (\# of the item in the scale) of EAEG 
DOI: 10.14807/ijmp.v12i4.1363

\begin{tabular}{ll}
\hline 1 \\
$\mathbf{2}$
\end{tabular}
Source: Adapted from Melo (2004)

\subsection{Job Satisfaction Scale (EST)}

EST built and validated in Siqueira (2008), has items that cover five theoretical dimensions related to job satisfaction, using the expression "satisfaction with" salary (s), colleagues $(c)$, leadership $(l d)$, promotions $(p)$, nature of work $(n w)$. The main objective is to identify the degree of satisfaction of employees regarding to their work environment.

According to Siqueira (2008), the complete version of the EST has 25 items (five items for each of the five dimensions). As it is a multidimensional measure, after its application, five general average scores $(\bar{v} d)$ must be computed, one for each dimension $(d)$ assessed. With an evaluation scale of the items $(i)$ of each dimension for each questionnaire $(q)$ composed of 7 scale-points ( 1 = totally dissatisfied; 2 = very dissatisfied; 3 = dissatisfied; 4 = indifferent; 5 = satisfied; 6 = very satisfied ; 7 = fully satisfied), $\bar{v} d$ results from the Equation (4):

$\bar{v} d=\left[\frac{(\text { Evidq })}{550}\right] ; q=1, \ldots, 110 ; i=1, \ldots, 5 ; d=1, \ldots, 5$

The result of each general average score will vary between $1 \leq \bar{v} d \leq 7$. The interpretation of the results should consider that the higher $\bar{v} d$ the greater the degree of employee satisfaction with that dimension of their work. According to Siqueira (2008), the ratio $1 \leq \bar{v} d \leq 3.9$ tends to indicate dissatisfaction; the ratio $4 \leq \bar{v} d \leq 4.9$ informs a state of indifference and the ratio $5 \leq \bar{v} d$ $\leq 7$ tends to suggest satisfaction. In this case, the individual assessment of the items in each dimension of the scale was not considered relevant to study because the universe of employees studied was considered homogeneous concerning the role performed within the organizations which they operate in. Table 3 presents the dimensions, definitions, items and the precision indexes (Cronbach's alpha) for each dimension of the EST (Siqueira, 2008). 
INDEPENDENT JOURNAL OF MANAGEMENT \& PRODUCTION (IJM\&P)

http://www.ijmp.jor.br

v. 12, n. 4, May-June 2021

ISSN: 2236-269X

DOI: $10.14807 /$ ijmp.v12i4.1363

Table 3: The five dimensions of the EST and the 25 items that comprise it

\begin{tabular}{|c|c|c|c|}
\hline Dimensions (d) & Definitions & Items (i) & $\begin{array}{c}\text { Cronbach } \\
\text { alfa }(\alpha)\end{array}$ \\
\hline $\begin{array}{l}\text { Satisfaction with } \\
\text { colleagues (c) }\end{array}$ & $\begin{array}{l}\text { Contentment with the collaboration, friendship, trust and the } \\
\text { relationship the leader maintains with co-workers. }\end{array}$ & $\begin{array}{c}1,6,14,17 \\
\text { e } 24\end{array}$ & 0,86 \\
\hline $\begin{array}{l}\text { Satisfaction with } \\
\text { salary (s) }\end{array}$ & $\begin{array}{l}\text { Contentment with the salary you receive compared to the } \\
\text { workload, professional capacity, cost of living and efforts } \\
\text { made in carrying out the work. }\end{array}$ & $\begin{array}{l}5,8,12,15 \\
\quad \text { e } 21\end{array}$ & 0,92 \\
\hline $\begin{array}{l}\text { Satisfaction with } \\
\text { management (ld) }\end{array}$ & $\begin{array}{l}\text { Contentment with the boss's organization and professional } \\
\text { capacity, his interest in the work of subordinates and } \\
\text { understanding between them. }\end{array}$ & $\begin{array}{l}2,9,19,22 \\
\quad \text { e } 25\end{array}$ & 0,90 \\
\hline $\begin{array}{l}\text { Satisfaction with the } \\
\text { nature of work (nw) }\end{array}$ & $\begin{array}{l}\text { Contentment with the interest the leader has for the tasks, with } \\
\text { the variety of these, and the ability to absorb the worker. }\end{array}$ & $\begin{array}{l}7,11,13, \\
18 \text { e } 23 \\
\end{array}$ & 0,82 \\
\hline $\begin{array}{l}\text { Satisfaction with } \\
\text { promotions (p) }\end{array}$ & $\begin{array}{l}\text { Contentment with the number of times that you have received } \\
\text { promotions, the guarantees offered to those who are } \\
\text { promoted, the way the company performs promotions and the } \\
\text { waiting time for the promotion. }\end{array}$ & $\begin{array}{l}3,4,10,16 \\
\text { e } 20\end{array}$ & 0,87 \\
\hline
\end{tabular}
Source: Adapted from Siqueira (2008, p. 269)

\section{RESULTS AND DISCUSSION}

The application of the questionnaire generated a total of 120 participations, totaling 5 IT companies. Regarding the participants' area of operation, the operational area (software development) prevailed. It was identified that the fact that $79 \%$ of employees have been in the company for less than 5 years is due to the interest of managers in attracting young graduates to guarantee career opportunities and professional experience for the operational staff.

Employees who accumulate permanence between 6 and 10 years are managers directly linked to the operational area, and employees who accumulate permanence between 11 and 15 years are those who currently hold leadership positions. Only $3 \%$ of respondents have been in the same company for more than 16 years. Only 116 individuals reported their ages, ranging from 19 to 39 years, with the average age of the participants in this research being 27 years.

Figure 2 shows the participants distribution by: (a) sex, and (b) time of working in the company.

(a)

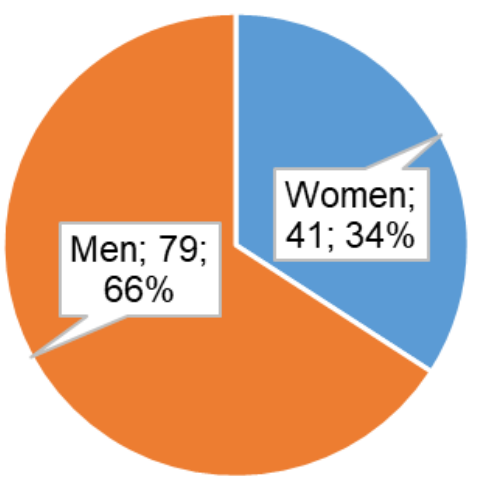

(b)

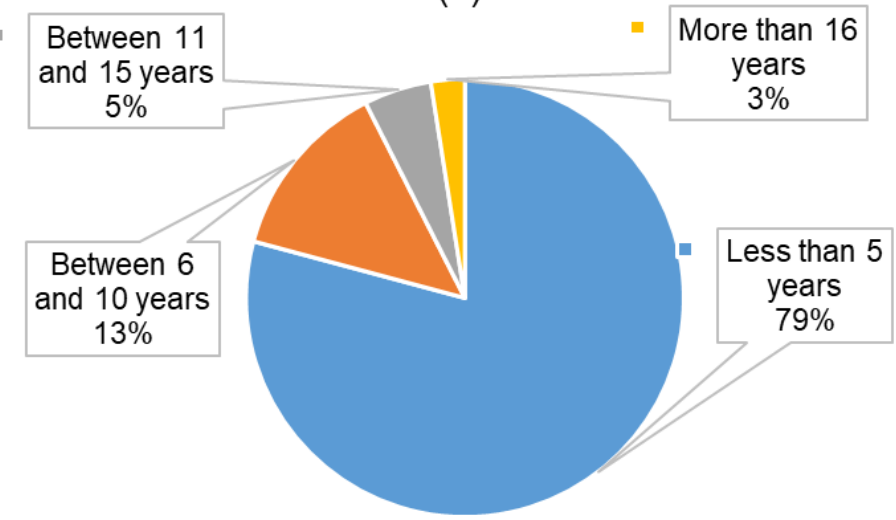

Figure 2: Distribution of research participants attending: (a) sex, (b) time in the company. 
DOI: 10.14807/ijmp.v12i4.1363

From 120 participations, only 110 were valid for analyzing the data regarding the relationship between managerial styles and the degree of satisfaction from the EST dimensions.

\subsection{EAEG on IT companies assessed}

After the statistical processing of the questionnaires, there was a general tendency to perceive the managerial style, according to the research participants, which prevails the style focused on the Task factor (Table 4).

In interviews carried out so that the participants could have access to the results of the questionnaires and contribute to the descriptive analysis of the results, it was inferred the fact that the Task factor prevails as a general trend of the managerial style may be a consequence of these employees in the operational area are involved with constant demands of IT projects, sometimes complex and with very tight deadlines. This generates a tendency for the leadership to exercise its performance more focused on fulfilling what must be done (execution and development tasks) so that the projects are delivered on the scheduled date without delay. With this objective, it is often not perceived that very excessive and uncontrolled demands can lead to the neglect of not establishing adequate professional bonds.

The general assessment of the interviewees indicated that sometimes the atmosphere within the team goes through moments of tension, given the demands and deadlines of the projects, and the relationship between team members with managers and leaders is difficult. About the performance of the staff members of the operational teams, a bias towards autonomy regarding to the execution of the work content was perceived.

Table 4 shows the statistical analysis done after processing the questionnaires, which confirms the analysis exposed above. The general score $(P)$ for each item $(i)$ of each factor $(f)$ results from Equation 5.

$$
P f i=\left(\sum_{q=1}^{n} \text { vif } / 110\right)
$$

Where $q$ represents each questionnaire. 
INDEPENDENT JOURNAL OF MANAGEMENT \& PRODUCTION (IJM\&P)

http://www.ijmp.jor.br

v. 12, n. 4, May-June 2021

ISSN: 2236-269X

DOI: $10.14807 /$ ijmp.v12i4.1363

Table 4: Statistical analysis to assess the predominant managerial style according to EAEG

Factors $(f)$

\begin{tabular}{|c|c|c|c|c|c|}
\hline Pfi & Task $(t)$ & Pfi & Relationship ( $r$ ) & Pfi & Situational (s) \\
\hline $\begin{array}{l}\text { Pt1 } \\
\text { Pt2 } \\
\text { Pt3 } \\
\text { Pt4 } \\
\text { Pt5 } \\
\text { Pt6 }\end{array}$ & $\begin{array}{l}4.00 \\
3.91 \\
4.45 \\
3.55 \\
4.64 \\
4.09\end{array}$ & $\begin{array}{l}\text { Pr } 1 \\
\text { Pr } 2 \\
\text { Pr } 3 \\
\text { Pr } 4 \\
\text { Pr } 5 \\
\text { Pr } 6 \\
\text { Pr } 7 \\
\text { Pr } 8 \\
\text { Pr } 9\end{array}$ & $\begin{array}{l}2.27 \\
1.91 \\
2.91 \\
3.00 \\
3.64 \\
1.85 \\
2.64 \\
3.55 \\
3.64\end{array}$ & $\begin{array}{l}P s 1 \\
P s 2 \\
P s 3 \\
P s 4\end{array}$ & $\begin{array}{l}2.45 \\
4.55 \\
2.27 \\
1.82\end{array}$ \\
\hline $\bar{v} t$ & 4.11 & $\bar{v} r$ & 2.82 & $\bar{v} s$ & 2.77 \\
\hline$S t$ & 0.39 & $S r$ & 0.71 & Ss & 1.21 \\
\hline At & 0.91 & $A r$ & 1.79 & As & 2.73 \\
\hline
\end{tabular}

The individual analysis of the questionnaires confirmed that 71 employees (65\%) indicated the Task focus as the main one in which managers operate, followed by 22 (20\%) that indicated the Relationship factor and 17 (15\%) the Situational factor.

\subsection{EST on IT companies assessed}

The analysis of the job satisfaction of the employees participating in this research showed that, with an index of $\bar{v} d=5.09$ related to the nature of the work, they are satisfied. This can indicate that employees feel engaged with their professional activities and like what they do.

An average score of $\bar{v} d=4.34$ indicated that, regarding the relationship with teammates and work, there is indifference, that is, they are not satisfied or dissatisfied. This relationship can be the result of the sometimes solitary work that involves the software development and IT projects, where each employee dedicates a lot of time to a very specific activity within the area, although sometimes he actively interacts with the other team members.

Next, the salary and promotions dimensions resulted, with an average score of $\bar{v} d=$ 3.87 and $\bar{v} d=3.70$, respectively, which indicates dissatisfaction in these aspects. This result can be correlated to the fact that, as $79 \%$ of the participants (95 employees) have worked for less than 5 years in the companies in which they operate (Figure 2), it seems to be the managers still does not consider this time enough to promote the position and the employees concerned.

With an average index of $\bar{v} d=3.46$, employees feel dissatisfied with their boss. In the interviews with the research participants, most agreed that the relationship with their immediate 
INDEPENDENT JOURNAL OF MANAGEMENT \& PRODUCTION (IJM\&P)

http://www.ijmp.jor.br

v. 12, n. 4, May-June 2021

ISSN: 2236-269X

DOI: $10.14807 /$ ijmp.v12i4.1363

superiors was very rigid because of the hierarchy and demands, which consequently contributes to having a somewhat negative organizational climate.

Table 5 presents the results obtained after processing the questionnaire data regarding the EST, representing the results described above. Pdi values were calculated based on Eq. (5).

Table 5: Average score for each dimension of the EST

\begin{tabular}{|c|c|c|c|c|}
\hline Dimensions & Items $(\tilde{i})$ & $P d i$ & Pdi/110 & $\bar{v} d$ \\
\hline \multirow{5}{*}{ Colleagues (c) } & 1 & 450 & 4.09 & \multirow{5}{*}{4.34} \\
\hline & 6 & 500 & 4.55 & \\
\hline & 14 & 470 & 4.27 & \\
\hline & 17 & 475 & 4.32 & \\
\hline & 24 & 490 & 4.45 & \\
\hline \multirow{5}{*}{ Salary (s) } & 5 & 425 & 3.86 & \multirow{5}{*}{3.87} \\
\hline & 15 & 400 & 3.64 & \\
\hline & 21 & 440 & 4.00 & \\
\hline & 2 & 435 & 3.95 & \\
\hline & 9 & 430 & 3.91 & \\
\hline \multirow{5}{*}{ Leadership (ld) } & 2 & 390 & 3.55 & \multirow{5}{*}{3.46} \\
\hline & 9 & 400 & 3.64 & \\
\hline & 19 & 380 & 3.45 & \\
\hline & 22 & 375 & 3.41 & \\
\hline & 25 & 360 & 3.27 & \\
\hline \multirow{5}{*}{ Nature of work $(n w)$} & 7 & 490 & 4.45 & \multirow{5}{*}{5.09} \\
\hline & 11 & 625 & 5.68 & \\
\hline & 13 & 480 & 4.36 & \\
\hline & 18 & 615 & 5.59 & \\
\hline & 23 & 590 & 5.36 & \\
\hline \multirow{5}{*}{ Promotions $(p)$} & 3 & 350 & 3.18 & \multirow{5}{*}{3.70} \\
\hline & 4 & 400 & 3.64 & \\
\hline & 10 & 420 & 3.82 & \\
\hline & 16 & 385 & 3.50 & \\
\hline & 20 & 480 & 4.36 & \\
\hline
\end{tabular}

\subsection{How to increase the level of job satisfaction?}

After the assessment done, it is clear that the degree of satisfaction tends to be lower in situations where there is an unhealthy relationship with the leadership and the work environment.

Melo (2004), mentions that the transformational leadership style is correlated with increased productivity and low voluntary turnover in organizations, as the motivations are linked to charisma and communication. However, it is still subject to restrictions for some scholars of organizational behavior, since it is a particular characteristic of an individual and not a group.

There is no formula to follow or the best style to lead, but there are characteristics and attitudes that are explicitly relevant to an individual who wants to be a successful leader and wants to positively impact his employees. Leaders oriented to train, inform, delegate, defend 
DOI: $10.14807 /$ ijmp.v12i4.1363

and animate, guarantee leadership on the path of success, managing to meet the team's desires, generate satisfaction and increase the performance of each employee, as stated by Marques (2019).

Foina and Eiras (2016) argue that due to the high turnover of IT professionals, their retention in companies has become a new challenge to be faced by the area dedicated to people management. The study carried out by these authors in three companies in the public and private sector, allowed to identify the profile of information technology professionals, in order to understand what their needs and motivations were within the work environment. The studied carried out by Foina and Eiras (2016) as well as the present work can serve as a basis to understand what can be improved to guarantee the job satisfaction of these professionals. The proposal of these authors, based on the research carried out, includes as main motivating elements of job satisfaction of IT employees:

1. A job that provides personal and professional balance.

2. Competitive salary, other benefits regarding time management itself.

3. Dynamic and challenging work, varied work content.

4. Possibility to develop innovative solutions and to carry out training and improvement courses, even outside working hours.

5. Ability to, through their work, influence the company's strategic decision-making.

6. Availability of adequate means of work, this influences the productivity and speed of the execution of activities.

7. Good organizational climate and professional recognition are motivating elements for staying in organizations.

8. Adequate strategic planning and execution of effective motivational campaigns to ensure employee retention.

9. Low risk as to the possibility of entering the labor market or changing jobs.

10. Indicate colleagues or friends to be part of the team.

These 10 elements were also fully confirmed in the interviews conducted with the participants of the current research. 
DOI: 10.14807/ijmp.v12i4.1363

\subsubsection{Management 3.0 - a new leadership vision}

The traditional way of managing has been migrating to the managerial model called Management 3.0, emerging with a new concept of leadership (Appelo, 2010). It is a set of tools and practices aimed at helping to manage an organization. Its ideals are based on energizing people, teams, reducing restrictions, developing skills and growing in structure through a realistic approach to lead, manage and improve teamwork.

This managerial model allows to apply practices and skills aimed at developing and managing happy people; analyzes the organization's system to find the right solutions for effective leadership. The tools aim to answer the questions: how can we measure performance? How can we reward people in a better way? How can we motivate teams? How can we change the organization's culture? Adopting this managerial model will help to enhance the team's interpersonal relationships, satisfaction and performance.

\section{CONCLUSIONS}

The objective of this work was to identify and evaluate which managerial styles prevail in the operational area of 5 companies of the IT sector and their relationship with the job satisfaction of these employees. A complementary bibliographic search made possible to identify relevant literature for studying the topic. The main instrument for the development of the research was the application of questionnaires and interviews to 110 employees.

The questionnaires integrated sociodemographic questions and those related to the managerial styles studied by EAEG from Melo (2004) and EST from Siqueira (2008), in order to compute statistically through descriptive analysis the managerial focus (EAEG) in which it operates the leadership of these companies and what is the relationship with job satisfaction regarding to the five dimensions of EST. Hence, it was concluded that:

1. In the evaluated companies, employees identified the managerial factor (EAEG) turned to the Task focus as the main one, with an average score $\bar{v} t=4.11$. This confirms that the relationship between leaders and teams prioritizes the execution of work to meet organizational schedules.

2. The dimension of the EST, Satisfaction with the nature of the work, according to the average score $\bar{v} d=5.09$ is related to the higher satisfaction of employees. Due to the autonomy concerning to the work's content and the domain of the activities to be carried 
DOI: 10.14807/ijmp.v12i4.1363

out, employees feel comfortable with the content that they perform daily given the variety of projects which they work in.

3. The dimension Satisfaction with colleagues, with an average score $\bar{v} d=4.34$, showed indifference on the level of satisfaction. This result may be related to the performance of very specific activities and with little interaction between colleagues.

4. The dimensions Satisfaction with the salary, Satisfaction with the promotions and Satisfaction with the boss presented levels of dissatisfaction with average scores $\bar{v} d=$ $3.87 ; \bar{v} d=3.70$ and $\bar{v} d=3.46$, respectively. This result is probably associated with the time working at the company (up to 5 years) of the majority of the interviewed employees, which the leadership may consider little time for salary increases and promotions.

5. Jobs that provide personal and professional balance, a competitive salary, adequate benefits, that allows managing one's own time, dynamic and challenging, innovative, that fosters improvement and training, influencing strategic decision-making, with the availability of adequate means of work, with a predominance of a good organizational climate and professional recognition are motivating elements for staying in organizations and contributing to the job satisfaction of these employees.

\section{REFERENCES}

Appelo, J. (2010). Management 3.0: Leading Agile Developers, Developing Agile Leaders. First Ed., Addison-Wesley Professional, The Netherlands.

Barbosa, F. M., Gambi, L. N., \& Gerolamo, M. C. (2017). Liderança e gestão de qualidade um estudo correlacional entre os estilos de liderança e princípios da gestão da qualidade.

Gestão \& Produção, 24(3), 438-449. http://dx.doi.org/10.1590/0104-530x2278-16

Batista, N. P. O., Kilimnik, Z. M., \& Neto, M. T. R. (2016). Influência dos estilos de liderança na satisfação no trabalho: um estudo em uma entidade de fins não econômicos.

Navus Revista de Gestão e Tecnologia, 6(3), 24-39.

Braga, A. A., Costa, D. M., \& Vecchia, D. C. (2014). A importância da liderança na gestão de TI. Revista Pensar Tecnologia, 1-12. Disponível em: http://revistapensar.com.br/tecnologia/pasta_upload/artigos/a58.pdf

Carvalho, J. A. (2010). Tecnologias e sistemas de informação: uma área científica orientada às necessidades de conhecimento dos profissionais envolvidos na contínua transformação das organizações através das tecnologias de informação. Revista Eletrônica de Biblioteconomia e Ciência da Informação, (2), 1-25. https://doi.org/10.5007/1518-2924.2010v15nesp2p1

Deal, T. E., \& Kennedy, A. (1983). Culture: a new look through old lenses. Journal of Applied Behavioral Science, 19(4), 498-505. https://doi.org/10.1177/002188638301900411 
DOI: $10.14807 /$ ijmp.v12i4.1363

Exame. (2014). Salário é maior insatisfação de profissionais de TI. Disponível em: $<$ https://exame.abril.com.br/carreira/salario-e-maior-insatisfacao-de-profissionais-de-ti/> Acesso em: 10 Jan. 2020.

Exame. (2015). O que “turbina” a satisfação no trabalho em 24 áreas. Disponível em: $<$ https://exame.abril.com.br/carreira/o-que-os-profissionais-de-24-setores-valorizam-notrabalho/> Acesso em: 10 Jan. 2020.

Foina, P. R. (2012). Tecnologia de informação: planejamento e gestão. São Paulo: Atlas.

Foina, P. R., \& Eiras, V. L. L. (2016). Os desafios motivacionais na gestão dos profissionais de TI: estudo de três empresas. Universitas Gestão e TI, Brasília, 6(2), 97-104.

Hellriegel, D., Slocum Jr., J. W., \& Woodman, R. W. (2001). Organizational behavior. 7ed. South-Western College, CA, USA.

Hunter, J. C. (2004). O Monge e o Executivo: Uma história sobre a essência da Liderança. Sextante, Rio de Janeiro, RJ, Brasil.

Judge, T. A., Piccolo, R. F., \& Ilies, R. (2004). The Forgotten Ones? The Validity of Consideration and Initiating Structure in Leadership Research. Journal of Applied Psychology, 89(1), 36-51. https://doi.org/10.1037/0021-9010.89.1.36

Leucotron. (2019). Como fazer uma liderança de TI que inspire os liderados. Disponível em: <https://blog.leucotron.com.br/como-fazer-uma-lideranca-de-ti-que-inspire-osliderados/>. Acesso em: 20 Dez. 2019.

Locke, E. A. (1969). What is job satisfaction? Organizational Behavior Human Performance, 4(4), 309-336. https://doi.org/10.1016/0030-5073(69)90013-0

Locke, E. A. (1976). The Nature and Causes of Job Satisfaction. In: Dunnette, M.D., Ed., Handbook of Industrial and Organizational Psychology, (1), 1297-1343.

Lopes, M. R., Yamada, J., \& Queiroz, A. F. (2017). Liderança em Tecnologia da Informação. Revista de Ciências Gerenciais, 21(34), 84-90. http://dx.doi.org/10.17921/14156571.2017v21n34p84-90

Maamari, B. E., \& Majdalani J. F. (2017). Emotional intelligence, leadership style and organizational climate. International Journal of Organizational Analysis, 25(2) 327-345. https://doi.org/10.1108/IJOA-04-2016-1010

Maio, T. L. (2016). A felicidade no trabalho: o impacto na gestão das organizações. Dissertação de Mestrado em Gestão, 73 p. Instituto Superior de Gestão. Business \& Economics School, Lisboa, Portugal.

Marques, J. C. (2019). Como funciona a Escala de Satisfação no Trabalho. Disponível em: $<$ https://www.jrmcoaching.com.br/blog/como-funciona-a-escala-de-satisfacao-no-trabalho/>. Acesso em: 16 jul. 2019.

Melo, E. A. A. (2004). Escala de avaliação de estilo gerencial (EAEG): desenvolvimento e validação. Revista Psicologia: Organizações e Trabalho, 4(2), 31-62.

Neves, J. G. (2001). Clima Organizacional, Cultura Organizacional e Gestão de Recursos Humanos. Editora RH, Lisboa, Portugal.

Nunes, W. P., \& Zanetti, E. (2017). Cultura e clima no contexto organizacional. Revista Científica Semana Acadêmica, 1, 1-17. 
DOI: $10.14807 /$ ijmp.v12i4.1363

Rossetti, A. G., \& Morales, A. B. (2007). O papel da tecnologia da informação na gestão do conhecimento. Ciência da Informação, 36(1), 124-135. http://dx.doi.org/10.1590/S010019652007000100009

Rueda, F. J. M., Santos, A. A. A., \& Lima, R. C. (2012). Relação entre satisfação no trabalho e clima organizacional: um estudo com trabalhadores. Boletim de Psicologia, 62(137), 129140.

Sant'anna, L. L., Paschoal, T., \& Gosendo, E. E. M. (2012). Bem-estar no Trabalho: Relações com Estilos de Liderança e Suporte para Ascensão, Promoção e Salários. Revista de Administração Contemporânea, 16(5), 744-764. http://dx.doi.org/10.1590/S141565552012000500007

Santos, J. V., \& Gonçalves, G. (2010). A cultura organizacional: O impacto visível de uma dimensão invisível. Revista de Psicologia, 41(3), 393-398.

Schein, E. H. (1992). Organizational culture and Leadership. 2 Ed. Jossey-Bass, San Francisco, CA, USA.

Siqueira, M. M. M. (2008). Escala de Satisfação no Trabalho - EST. In: Siqueira, M. M. M. e colaboradores, Medidas do comportamento organizacional. (pp. 265-274). Porto Alegre: Artmed.

Souza, E. G. (2004). Cultura e motivação dos profissionais de tecnologia da informação no Brasil.

Turano, L. M., \& Cavazotte, F. (2016). Conhecimento Científico sobre Liderança: Uma Análise Bibliométrica do Acervo do The Leadership Quarterly. Revista de Administração Contemporânea, 20(4), 434-457. http://dx.doi.org/10.1590/1982-7849rac2016140075

Vroom, V. H. (1994). Work and motivation. First Ed. John Wiley \& Sons, New York, NY, USA.

Warr, P. B. (2007). Work, happiness and unhappiness. First Ed. Routledge, New York, NY, USA. 